\title{
Studies on Effect of Different Plant Spacing with Respect to Growth, Yield and Quality of Broccoli (Brassica oleracea var. italica. L) under North Gujarat Conditions
}

\author{
T. Tejaswini", L.R. Varma, P. Verma, D.M. Thakur and F.B. Vani \\ Department of Vegetable Science, College of Horticulture, SD Agricultural University, \\ Sardarkrushinagar - 385506, Gujarat, India \\ *Corresponding author
}

\begin{abstract}
A B S T R A C T

\begin{tabular}{|l|}
\hline Ke y w o r d s \\
$\begin{array}{l}\text { Broccoli, Spacings, } \\
\text { Growth, Growth } \\
\text { attributes, Yield and } \\
\text { quality parameters }\end{array}$ \\
\hline Article Info \\
\hline $\begin{array}{l}\text { Accepted: } \\
\text { 04 April } 2018 \\
\text { Available Online: } \\
10 \text { May } 2018\end{array}$ \\
\hline
\end{tabular}

The present investigation was carried out at Horticulture Instructional Farm, CP College of Agriculture, SD Agricultural University, Sardarkrushinagar, Gujarat to find out the effect of different plant spacing on growth, yield and quality of broccoli (Brassica oleracea var. italica. L). Three plant spacings viz., $S_{1}-30 \mathrm{~cm} \times 30 \mathrm{~cm}, \mathrm{~S}_{2}-45 \mathrm{~cm} \times 30 \mathrm{~cm}$ and $\mathrm{S}_{3}-45$ $\mathrm{cm} \times 45 \mathrm{~cm}$ was analyzed statistically on growth, growth attributes, yield and quality parameters of broccoli and are summarized below. The results revealed that the treatment $\mathrm{S}_{1}(30 \mathrm{~cm} \times 30 \mathrm{~cm})$ attained significantly maximum plant height at transplanting $(21.90$ $\mathrm{cm})$, at 45 DAT $(39.35 \mathrm{~cm})$ and at harvest $(57.67 \mathrm{~cm})$, minimum number of days taken for head initiation (61.48) and head harvest (81.37), maximum yield per plot $(5.73 \mathrm{~kg})$ and yield per hectare $(219.36 \mathrm{q})$. Whereas significantly maximum plant spread E-W $(50.36 \mathrm{~cm})$ \& N-S $(49.91 \mathrm{~cm})$ at 45 DAT \& at harvest E-W $(62.15 \mathrm{~cm}) \& \mathrm{~N}-\mathrm{S}(62.12 \mathrm{~cm})$, highest head diameter $(14.10 \mathrm{~cm})$, fresh weight of head $(275.53 \mathrm{~g})$, total dry matter content of the head $(19.81 \%)$, crude protein content $(2.91 \%)$, potassium content $(464.2 \mathrm{mg})$ and calcium content $(42.65 \mathrm{mg})$ were recorded with the wider plant spacing treatment $S_{3}(45 \mathrm{~cm} \mathrm{x} 45$ $\mathrm{cm})$.
\end{abstract}

\section{Introduction}

Broccoli (Brassica oleracea var. italica L.) is an important fancy and highly nutritive exotic vegetable. It is a member of cruciferous family having many important vegetables such as Cauliflower, Cabbage, Knol-khol, Brussels sprout, Kale and Chinese cabbage. It is also known as winter broccoli or heading broccoli or Italian broccoli. It is considered to be originated from wild cabbage, Brassica oleracea var. oleracea (syn. Brassica oleracea 
carbohydrates $(5.9 \mathrm{~g})$ and minerals like calcium (103 mg), iron (1.1 mg), phosphorous (78 mg), potassium (382 $\mathrm{mg})$ and sodium (15 $\mathrm{mg}$ ) per $100 \mathrm{gm}$ of edible portion (Rana, 2008). After harvesting the head, its green leaves are also a good source of nutritious green fodder and serves in acute shortage in winter season (Kumar et al., 2007).

In India, it is being used as a fresh vegetable, where as in USA and European countries it is used as fresh as well as frozen form. It is usually boiled or steamed but may be eaten raw as salad and is liked in soups. The anticancer benefits of broccoli are greatly reduced if the vegetable is boiled. However, other preparation method such as steaming, microwaving and frying had no significant effect on the constituent compounds (Jeffery, 2005).

There are two types of broccoli, heading and sprouting. Most common broccoli is of the heading type which is closely related to cauliflower and forms a large central head. Sprouting or Italian broccoli form many florets or small heads but they do not produce a solid head. Its edible portion consists of immature, fully-differentiated flower buds and tender portions of the upper stem.

The growth, yield and quality of crop plants are mainly influenced by two principal factors viz., genetical and cultural or management factors. The first factor deals with the various breeding techniques for the improvement in crop varieties. The second factor deals with the horticultural practises viz., plant population, date of planting, fertilizer dose, irrigation, and weed control etc. Among them plant population per unit area is very important.

Plant population per unit area plays an important role in growth and development of the crop. Optimum plant spacing is one of the important factors in increasing the yield and quality of crops. Therefore, present studies were aimed at promotion of high valued broccoli by identifying and standardization of optimum plant spacing to obtain better growth, yield and quality of broccoli is important for North Gujarat.

\section{Materials and Methods}

The present investigation was executed at Horticulture Instructional Farm, CP College of Agriculture, Sardarkrushinagar Dantiwada Agricultural University, Sardarkrushinagar, Gujarat during the year 2015-16. The experiment was laid out in a split plot design with three replications. The experimental area was divided into plots of $2.70 \mathrm{~m}$ x $1.80 \mathrm{~m}$ size. The experiment was carried out with three different plant spacing $\left(\mathrm{S}_{1^{-}} 30 \mathrm{~cm} \times 30 \mathrm{~cm}, \mathrm{~S}_{2^{-}}\right.$ $45 \mathrm{~cm} \times 30 \mathrm{~cm}$ and $\left.S_{3^{-}} 45 \mathrm{~cm} \times 45 \mathrm{~cm}\right)$. To raise the crop recommended package of practices was followed. The date of seed sowing in nursery bed was on $23^{\text {rd }}$ November 2015 and date of transplanting on $17^{\text {th }}$ December 2015 during Rabi season. The effect of different plant spacing treatments was studied and data recorded on germination, plant height (at transplanting, 45 days after transplanting, at harvest), number of leaves (45 days after transplanting, at harvest), plant spread (45 days after transplanting, at harvest), days taken for head initiation, days taken for harvesting, yield and quality parameters. The mean data were subjected to statistical analysis following analysis of variance technique (Panse and Sukhatme, 1985).

\section{Results and Discussion}

\section{Growth parameters}

\section{Days taken for germination}

Data on number of days taken for germination recorded from different plant spacing are 
furnished in table 1 and was found to be not significant.

Plant height at the time of transplanting, at 45 days after transplanting and at harvest (cm)

Influence of different plant spacing with respect to height of the seedlings at the time of transplanting, 45 days after transplanting and at harvest are presented in table 1. The effect of different plant spacing on height of seedlings at the time of transplanting was found not significant.

The effect of different plant spacing with respect to plant height at 45 DAT $(\mathrm{cm})$ was found significant. The significantly maximum plant height $(39.35 \mathrm{~cm})$ was found with the treatment $\mathrm{S}_{1}(30 \mathrm{~cm} \times 30 \mathrm{~cm})$.

The minimum plant height $(33.99 \mathrm{~cm})$ was recorded with treatment $S_{3}(45 \mathrm{~cm} \times 45 \mathrm{~cm})$. This might be due to more terminal increase in closer spaced plants than wider spaced plants, where lateral growth is more. These findings are in close conformity with the findings of Rahman et al., (2007) in cauliflower, Saikia et al., (2010) and Gurjeet et al., (2016) in broccoli.

The effect of different plant spacing with respect to plant height at the stage of head harvest was found significant. The significantly maximum plant height (57.67 $\mathrm{cm})$ was found with the treatment $S_{1}(30 \mathrm{~cm} \times$ $30 \mathrm{~cm})$. The treatment $S_{1}$ was statistically at par with treatment $S_{2}(45 \mathrm{~cm} \times 30 \mathrm{~cm})(56.07$ $\mathrm{cm})$. The minimum plant height $(51.19 \mathrm{~cm})$ was obtained with treatment $\mathrm{S}_{3}(45 \mathrm{~cm} \times 45$ $\mathrm{cm})$. This may be due to closer plant spacing leads to more terminal growth than the wider plant spacing. These findings are in close accordance with the findings of Saikia et al., (2010), Solunke et al., (2011), Gogoi et al., (2016) and Vinod et al., (2017) in broccoli.

\section{Number of leaves at 45 DAT and at harvest}

Effects of different plant spacings with respect to number of leaves at 45 DAT and at harvest was found to be not significant and are presented in table 2 .

\section{Plant spread (E-W and N-S) at 45 DAT and at harvest}

Influence of different plant spacings with respect to plant spread $(\mathrm{E}-\mathrm{W})$ and $(\mathrm{N}-\mathrm{S}) \mathrm{cm}$ at 45 DAT and at harvest are presented in table 2. The effect of different plant spacings with respect to plant spread (E-W) and $(\mathrm{N}-\mathrm{S})$ at 45 DAT was found significant. The significantly maximum plant spread [E-W $(50.36 \mathrm{~cm})$ and $\mathrm{N}-\mathrm{S}(49.91 \mathrm{~cm})]$ was found with treatment $\mathrm{S}_{3}$ $(45 \mathrm{~cm} \times 45 \mathrm{~cm})$. The minimum plant spread [E-W $(42.92 \mathrm{~cm})$ and N-S $(39.62 \mathrm{~cm})]$ was recorded with treatment $S_{1}(30 \mathrm{~cm} \times 30 \mathrm{~cm})$.

Wider plant spacing leads to good growth and development, less competition for the uptake of nutrients, water and sunlight, which leads to more lateral growth and spread. These findings are in accordance with the findings of Munro et al., (2007), Kumar et al., (2007), Saikia et al., (2010) and Bhangre et al., (2001) in broccoli.

The effect of different plant spacings with respect to plant spread [E-W and $\mathrm{N}-\mathrm{S}]$ at harvest was found to be significant. The significantly maximum plant spread $[\mathrm{E}-\mathrm{W}$ $(62.15 \mathrm{~cm})$ and N-S $(62.12 \mathrm{~cm})]$ was found with treatment $\mathrm{S}_{3}(45 \mathrm{~cm} \times 45 \mathrm{~cm})$. The minimum plant spread [E-W $(57.37 \mathrm{~cm}$ and N$\mathrm{S}(54.00 \mathrm{~cm})]$ was recorded with treatment $\mathrm{S}_{1}$ $(30 \mathrm{~cm} \times 30 \mathrm{~cm})$. These might be due to wider plant spacing leads to the maximum plant spread which might be due to more availability of sunlight, nutrients and water. These findings are in accordance with the findings of Munro et al., (2007), Kumar et al., (2007), Saikia et al., (2010) and Bhangre et al., (2001) in broccoli. 
Table.1 Effect of different plant spacing with respect to days taken for germination, plant height at the time of transplanting, 45DAT and harvesting

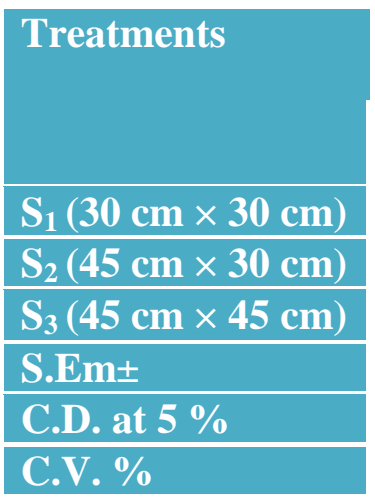

\begin{tabular}{|c|c|c|c|}
\hline \multirow{2}{*}{$\begin{array}{c}\text { Days taken for } \\
\text { germination }\end{array}$} & \multicolumn{3}{|c|}{ Plant height at(cm) } \\
\cline { 2 - 4 } & Transplanting & 45DAT & Harvesting \\
\hline 3.84 & 21.90 & 39.35 & 57.67 \\
\hline 3.75 & 20.95 & 34.96 & 56.07 \\
\hline 3.75 & 20.62 & 33.99 & 51.19 \\
\hline 0.06 & 0.433 & 0.615 & 1.152 \\
\hline NS & NS & 2.42 & 4.52 \\
\hline 5.47 & 7.10 & 5.90 & 7.26 \\
\hline
\end{tabular}

Table.2 Effect of different plant spacing with respect to number of leaves per plant at 45 DAT and harvesting, plant spread at 45 DAT and harvesting

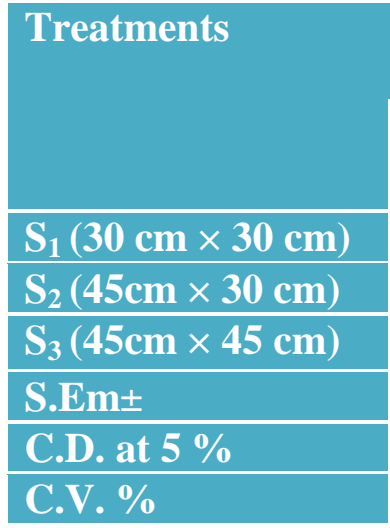

\begin{tabular}{|c|c|}
\hline \multicolumn{2}{|c|}{ Number of leaves per plant } \\
\hline 45 DAT & Harvesting \\
\hline 10.63 & 19.68 \\
\hline 10.37 & 20.14 \\
\hline 11.42 & 21.30 \\
\hline 0.307 & 0.560 \\
\hline NS & NS \\
\hline 10.03 & 9.52 \\
\hline
\end{tabular}

\begin{tabular}{|c|c|c|c|}
\multicolumn{4}{|c|}{ Plant spread (cm) } \\
\hline \multicolumn{2}{|c|}{ 45 DAT } & \multicolumn{2}{c|}{ Harvesting } \\
\hline (E-W) & $\mathbf{( N - S )}$ & $(\mathbf{E}-\mathbf{W})$ & $\mathbf{( N - S )}$ \\
\hline 42.92 & 39.62 & 57.37 & 54.00 \\
\hline 44.13 & 44.65 & 57.61 & 58.41 \\
\hline 50.36 & 49.91 & 62.15 & 62.12 \\
\hline 0.666 & 1.212 & 0.956 & 1.112 \\
\hline 2.614 & 4.757 & 3.753 & 4.364 \\
\hline 5.04 & 9.38 & 5.61 & 6.62 \\
\hline
\end{tabular}

Table.3 Effect of different plant spacing with respect to days taken for head initiation, days taken for head harvesting, head diameter, yield per plant $(\mathrm{g})$, yield per plot $(\mathrm{kg})$ and yield per hectare $(\mathrm{q})$

\begin{tabular}{|c|c|c|c|c|c|c|}
\hline Treatments & $\begin{array}{c}\text { Days } \\
\text { taken for } \\
\text { head } \\
\text { initiation }\end{array}$ & $\begin{array}{l}\text { Days taken } \\
\text { for head } \\
\text { harvesting }\end{array}$ & $\begin{array}{l}\text { Head } \\
\text { diamet } \\
\text { er }(\mathrm{cm})\end{array}$ & $\begin{array}{c}\text { Yield per } \\
\text { plant (Fresh } \\
\text { weight of } \\
\text { head) (g) }\end{array}$ & $\begin{array}{l}\text { Yield } \\
\text { per } \\
\text { plot } \\
\text { (kg) }\end{array}$ & $\begin{array}{c}\text { Yield } \\
\text { per } \\
\text { hectare } \\
(q)\end{array}$ \\
\hline $\mathrm{S}_{1}(30 \mathrm{~cm} \times 30 \mathrm{~cm})$ & 61.48 & 81.37 & 11.8 & 220.8 & 5.73 & 219.3 \\
\hline $\mathrm{S}_{2}(45 \mathrm{~cm} \times 30 \mathrm{~cm})$ & 65.53 & 86.27 & 12.8 & 236.3 & 2.99 & 127.0 \\
\hline $\mathrm{S}_{3}(45 \mathrm{~cm} \times 45 \mathrm{~cm})$ & 68.93 & 87.85 & 14.1 & 275.5 & 1.66 & 111.5 \\
\hline S.Em \pm & 0.47 & 0.60 & 0.40 & 10.59 & 0.097 & 7.407 \\
\hline C.D. at $5 \%$ & 1.86 & 2.38 & 1.58 & 41.61 & 0.38 & 29.07 \\
\hline C.V. \% & 2.50 & 2.46 & 10.8 & 15.04 & 9.74 & 16.81 \\
\hline
\end{tabular}


Table.4 Effect of different plant spacing with respect to quality parameters

\begin{tabular}{|c|c|c|c|c|}
\hline Treatments & $\begin{array}{l}\text { Total dry matter } \\
\text { content of the head } \\
(\%)\end{array}$ & $\begin{array}{c}\text { Crude } \\
\text { protein } \\
(\%)\end{array}$ & $\begin{array}{l}\text { Potassium } \\
\text { (mg/100gm) }\end{array}$ & $\begin{array}{l}\text { Magnesium } \\
\text { (mg/100gm) }\end{array}$ \\
\hline $\mathrm{S}_{1}(30 \mathrm{~cm} \times 30 \mathrm{~cm})$ & 19.68 & 2.89 & 459.2 & 42.32 \\
\hline $\mathrm{S}_{2}(45 \mathrm{~cm} \times 30 \mathrm{~cm})$ & 19.80 & 2.85 & 460.8 & 42.62 \\
\hline $\mathrm{S}_{3}(45 \mathrm{~cm} \times 45 \mathrm{~cm})$ & 19.81 & 2.91 & 464.2 & 42.65 \\
\hline S.Em \pm & 0.19 & 0.04 & 3.26 & 0.43 \\
\hline C.D. at $5 \%$ & NS & NS & NS & NS \\
\hline C.V. \% & 3.39 & 5.38 & 2.65 & 3.54 \\
\hline
\end{tabular}

\section{Days taken for head initiation}

Influences of different plant spacings with respect to days taken for head initiation are presented in table 3 .

Effect of different plant spacings with respect to days taken for head initiation was found significant. The significantly minimum days taken for head initiation (61.48 days) were recorded with treatment $S_{1}(30 \mathrm{~cm} \times 30 \mathrm{~cm})$. The maximum number day taken for head initiation (68.93 days) was observed with treatment $S_{3}(45 \mathrm{~cm} \times 45 \mathrm{~cm})$. The significant difference in days taken for head initiation by different plant spacing might be due to closer pant spacing. These findings are in accordance with the findings of Sorensen and Grevsen (1994), Singh et al., (2006), Rahman et al., (2007) in cauliflower, Saikia et al., (2010) and Bhangre et al., (2011), Thirupal et al., (2014) and Vinod et al., (2017) in broccoli.

\section{Days taken for first head harvesting}

Influences of different plant spacing with respect to number of days taken for first head harvest are presented in table 3.

Effect of different plant spacing with respect to number of days taken for first head harvest was found significant. The significantly minimum day taken for first head harvest
(81.37 days) was recorded with treatment $S_{1}$ $(30 \mathrm{~cm} \times 30 \mathrm{~cm})$. The maximum number of days taken for first head harvest (87.85 days) was observed with treatment $S_{3}(45 \mathrm{~cm} \times 45$ $\mathrm{cm})$. The significant difference in days taken for first head harvest by different plant spacing might be due to early head initiation and development of small head. Wider spacing leads to large head size, which requires more number of days for food accumulation and to prepare photosynthetases. These findings are in accordance with the findings of Sorensen and Grevsen. (1994), Singh et al., (2006), Singhal et al., (2009), Saikia et al., (2010) in broccoli, Moniruzzaman (2011) in cabbage and Bhangre et al., (2011) in broccoli.

\section{Yield parameters}

Influences of different plant spacings with respect to head diameter $(\mathrm{cm})$, yield per plant, yield per plot and yield per hectare are presented in table 3 .

\section{Head diameter}

Effect of different plant spacing with respect to head diameter was found significant and was shown in the table 3 . The significantly maximum head diameter $(14.1 \mathrm{~cm})$ was obtained with treatment $\mathrm{S}_{3}(45 \mathrm{~cm} \times 45$ $\mathrm{cm})$. The treatment $S_{3}$ was significantly at par with treatment $S_{2}(45 \mathrm{~cm} \times 30 \mathrm{~cm})(12.8 \mathrm{~cm})$. 
The minimum head diameter $(11.8 \mathrm{~cm})$ was obtained with treatment $S_{1}(30 \mathrm{~cm} \times 30 \mathrm{~cm})$. This might be due to more food accumulation in the plant which was grown at wider plant spacing, therefore head weight will be more which further shows more head diameter. These findings are in accordance with the findings of Sharif (2008), Hossain et al., (2011), Thirupal et al., (2014), Gurjeet (2016) and Vinod et al., (2017) in broccoli.

\section{Yield per plant (fresh weight of head)}

The significantly maximum fresh weight of the head $(275.53 \mathrm{~g})$ was obtained with treatment $S_{3}(45 \mathrm{~cm} \times 45 \mathrm{~cm})$. The treatment $\mathrm{S}_{2}(45 \mathrm{~cm} \times 30 \mathrm{~cm})$ was found statistically at par with treatment $S_{3}$. The minimum fresh weight of head $(220.8 \mathrm{~g})$ was observed with treatment $\mathrm{S}_{1}(30 \mathrm{~cm} \times 30 \mathrm{~cm})$.

The significant differences among different plant spacing with respect to fresh weight of head was due to good growth occurrence in wider plant spacing, more interception of light, less competition for moisture and nutrients which increases photosynthesis and accumulation of photosynthates in the main head. These finding are in accordance with the findings of Dev. H (2012), Bhangre et al., (2011), Gurjeet et al., (2015), Thirupal et al., (2014) and Vinod et al., (2011) in broccoli.

\section{Yield per plot}

The significantly maximum head yield per plot $(5.73 \mathrm{~kg})$ was recorded with treatment $S_{1}$ $(30 \mathrm{~cm} \times 30 \mathrm{~cm})$. The minimum head yield per plot $(1.66 \mathrm{~kg})$ was obtained with treatment $\mathrm{S}_{3}(45 \mathrm{~cm} \times 45 \mathrm{~cm})$. The variation in yield of head per plot at different plant spacings may be due to maximum plant density i.e. more number of plants per plot. This type of results was also reported by Sharma et al., (2005) in Brussels sprout, Singh et al., (2006) in cauliflower, Sharif et al., (2008), Saikia et al.,
(2010) in Fabek et al., (2011), Hossain et al., (2011), Khatun et al., (2011), Solunke et al., (2011), Gogoi et al., (2016) and Vinod et al., (2017) in broccoli.

\section{Yield per hectare}

The significantly maximum head yield per hectare $(219.36$ q) was obtained with treatment $S_{1}(30 \mathrm{~cm} \times 30 \mathrm{~cm})$. The minimum head yield per hectare $(111.59$ q) was obtained with treatment $S_{3}(45 \mathrm{~cm} \times 45 \mathrm{~cm})$. The main reason for maximum yield per hectare in closer plant spacing was due to higher plant population per unit area. These findings are in close accordance with the finding of Bhangre et al., (2011), Saikia et al., (2010), Fabek et al., (2011), Hossain et al., (2011), Khatun et al., (2011), Solunke et al., (2011), Gogoi et al., (2016) and Vinod et al., (2017) in broccoli.

\section{Quality parameters}

Influences of different plant spacings with respect to total dry matter content of the head, crude protein, potassium and magnesium content are presented in table 4 .

The plant density $S_{3}(45 \mathrm{~cm} \times 45 \mathrm{~cm})$ recorded the highest values for different quality parameters viz., Total dry matter content of the head $(19.81 \%)$, Crude protein (2.91\%), Potassium (464.2 $\mathrm{mg} / 100 \mathrm{gm})$, Magnesium $(42.65 \mathrm{mg} / 100 \mathrm{gm})$ were shown in the table 4 . These results were in conformity with the findings of Bhangre et al., (2011), El-Magd et al., (2006) and Islam et al., (2015) in broccoli. Kalloo et al., (2005) in vegetable pea, Lal (1996) in cabbage Uddain et al., (2012) in Knol-khol and Chandan et al., (2013) in broccoli.

In conclusion, from the above investigations it can be concluded that the treatment $S_{1}(30 \mathrm{~cm}$ x $30 \mathrm{~cm}$ ) attained significantly maximum 
plant height at transplanting $(21.90 \mathrm{~cm})$, at 45 DAT $(39.35 \mathrm{~cm})$ and at harvest $(57.67 \mathrm{~cm})$, minimum number of days taken for head initiation (61.48) and head harvest (81.37), maximum yield per plot $(5.73 \mathrm{~kg})$ and yield per hectare (219.36 q). Whereas significantly maximum plant spread E-W $(50.36 \mathrm{~cm})$ and $\mathrm{N}-\mathrm{S}(49.91 \mathrm{~cm})$ at $45 \mathrm{DAT}$ and at harvest E$\mathrm{W}(62.15 \mathrm{~cm})$ and $\mathrm{N}-\mathrm{S}(62.12 \mathrm{~cm})$, highest head diameter $(14.10 \mathrm{~cm})$, fresh weight of head $(275.53 \mathrm{~g})$, dry matter percent of head $(19.81 \%)$, protein content (2.91\%), potassium content $(464.2 \mathrm{mg})$ and calcium content $(42.65 \mathrm{mg})$ were recorded with the wider plant spacing treatment $S_{3}(45 \mathrm{~cm} \times 45$ $\mathrm{cm})$.

\section{References}

Bhangre, K.K., Sonawane, P. C and Warade, S. D. (2011). Effect of different varieties and spacing on growth and yield parameters of broccoli (Brassica oleracea var.italica) under Pune conditions, Asian Journal of Horticulture. 6(1):74-76.

Chandan, K., Raturi, H. C. and Uniyal, S.P. (2013). Performance of cabbage hybrids under rainfed mid-hill conditions of Uttarakhand. The Asian Journal of Horticulture. 8(1):110-113.

Dev, H. (2012) Standardization of planting time and spacing in broccoli cv Green Head for lower hills of northern India. International Journal of Farm Science. 2:36-42.

El-Magd, M. M. A., El-Bassiony, A.M. and Fawzy, Z.F. (2006). Effect of organic manure with or without chemical fertilizers on growth, yield and quality of some varieties of broccoli plants. Journal of Applied Science Research. 2(10):791-798.

Fabek, S., Toth, N., Benko, B. and Peic, I. (2011). The effect of plant density on morphological traits and yield of broccoli. Glasnik Zastite Bilja. 34 (1):22-29.

Gogoi, S., Millu, R., Das, P., Bora, N. and Das, B. K. (2016). Effect of sowing dates and spacing on broccoli (Brassica oleracea var. italica) seed production. Indian Journal of Agricultural Research. 50(4):350-353.

Guo, J. H., Lee, S., Chiang, F. and Chang, C. (2001). Antioxidant properties of the extracts from different parts of broccoli in Taiwan. Journal of food and Dry Analysis. 9:96-101.

Gurjeet, K. (2016). Growth, yield and quality of broccoli (Brassica oleracea var. italica). As influenced by nitrogen and plant population under different dates of sowing. Thesis (unpublished). Punjab Agricultural University, Ludhiana. (India).

Hossain, M. F, Ara, N, Uddin, M.R, Dey, S and Islam, M.R. (2011). Effect of time of sowing and plant spacing on broccoli production. Tropical Agricultural Research and Extension. 14(4): 90-92.

Jeffery, 2005. Maximizing the anti-cancer power of broccoli. Science daily, 5th, April, 2005. www.sciencedaily.com/ releases/2005/03/050326114810.htm.

Kalloo, G., Rai, M., Singh, J., Varma, A., Kumar, R., Rai, G.K. and Vishwanath (2005). Morphological and biological variability in vegetable pea (Pisum sativum L.). Vegetable Science., 32(1): 19-23

Khan, B., Shillong, A., Phillip, G., Brusewitz, H. and Mc New Ronald, W. (1991). Forceto shear the stalk, stalk diameter and yield of broccoli in response of nitrogen fertilization and within row spacing. Journal of American Society Horticultural Science. 116(2): 222-227.

Khatun, K., Saha, S. R. and Mostrain, T. (2011). Growth and yield of broccoli as influenced by plant spacing. 
International Journal of sustainable Agricultural Technology. 7(12):7-12.

Kumar, N., Praskash, V. and Srivastva, A.K. (2007). Effect of transplanting dates and geometries on broccoli (Brassica oleracea var. italica) under mid hill conditions of North- West Himalaya. Indian Journal of Agricultural sciences. 77(7):448-450.

Kunicki, E, Capecka, E, Siwek, P and Kalisz, A. (1999). The effect of plant spacing on the yield and quality of three broccoli cultivars in autumn growing. Folia Horticulture. 11(2): 69-79.

Lal, G. (1996). Effect of nitrogen and spacing on yield and quality of cabbage (Brassica oleracea L. var. capitata). Annuals of Biology. 12(2): 242-244.

Moniruzzaman. M. (2011). Effect of plant spacings on the performance of hybrid cabbage (Brassica oleracea var. capitata) varieties. Bangladesh Journal of Agriculture Research. 36(3): 495506.

Munro, D. C., Mackay, D. C. and Cutcliffe, J. A. (2007) Relation of nutrient content of broccoli and brussels sprouts leaves to maturity and fertilization with $\mathrm{N}, \mathrm{P}$ and $\mathrm{K}$ fertilizer. Canada Journal of Plant Sciences.58: 385-94.

Rahman, M. U., IqbalJilani, M.S and Waseem, K. (2007). Effect of different plant spacing on the production of cauliflower (Brassica oleracea var. botrytis) under the agro-climatic conditions of D.I. Khan. Pakistan Journal of Biological Sciences. 10 (24): 4531- 4534.

Rana, M.K. (2008). Olericulture in India. Kalyani Publishers, New Delhi. Pp: 301

Saikia Phookan, D.B. and Sanchita Brahma. (2010). Effect of time of planting and planting densities on growth, yield and economic production of broccoli (Brassica oleracea var. italica) cv. Pusa
Broccoli KTS-1. Journal of Hill Agriculture. 1(2): 135-139.

Sharif, A. A. (2008) Effects of spacing and potassium on growth and yield of broccoli (Brassica oleracea. var. italica L.). M.sc. Thesis (unpublished). Sher-EBhangla Agricultural University, Dhaka.

Sharma, A., Sonia, S., Sharma, J.J. and Kumar, R. (2005). Effect of Planting date, plant density and fertilizer levels on sprouts yield and yield attributing characters of brussels sprout (Brassica oleracea var. gemmifera) under high hill dry temperate conditions of northwest Himalayas. Indian Journal of Agricultural Science. 75(5): 292-293.

Singh, R., Chaursasia, S. N. S and Singh, S. N. (2006). Response of nutrient sources and spacing on growth and yield of broccoli (Brassica oleracea var. italica). Vegetable science. 33:198-200.

Singh, R.V. and Naik, L.B. (2006). Response of broccoli (Brassica oleracea var. italica) to plant spacing, nitrogen and phosphorus levels. Indian Journal of Horticulture. 45(3-4): 325-328.

Singhal, B., Preeti. K., Srivastava, B.K., Singh, M.P. and Singh, P.K. (2009). Effect of date of planting and spacing on the performance of broccoli. Indian Journal of Horticulture. 66(1): 137-140.

Solunke, B.G., Wagh, A.P., Dod, V.N. and Nagre, P.K. (2011). Effect of dates of planting and spacing on performance of different cultivars on growth and yield of broccoli. The Asian Journal of Horticulture. 6(2): 294-296.

Sorensen and Grevsen. (1994). Effect of plant spacing on uniformity in broccoli for once-over harvest. Gartenbauwissens chaft. 59(5): 102-105.

Thirupal, D., Madhumathi, C. and Reddy, P. S. S. (2014) Effects of planting dates and plant spacing on growth, yield and quality of broccoli under Rayalaseema 
zone of Andhra Pradesh, India. Plant Archives. 14:1095-98.

Uddain, J., Liton, M. M. U. A. and Rahman, M. S. (2012). Organic farming practices on different kohl-rabi (Brassica oleracea var. gongylodes L.) cultivars. International Journal of Bio-resource and stress management. 3(3).

Vinod sutar; Aravindakshan, K. and Bola, P.K. (2017). Effect of sowing date and spacing on growth, yield and quality of broccoli (Brassica oleracea var. italica) cultivar. Green head. Chemical science review and letters. 6(21): 209-212. Yadav, M., Prasad, V. M. and Ahirwar, C.S. (2013). Varietal evolution of cauliflower (Brassica oleracea var. botrytis L.) in Allahabad agro-climate condition. Trends in biological science. 6(1): 99-100.

\section{How to cite this article:}

Tejaswini, T., L.R. Varma, P. Verma, D.M. Thakur and Vani, F.B. 2018. Studies on Effect of Different Plant Spacing with Respect to Growth, Yield and Quality of Broccoli (Brassica oleracea var. italica. L) under North Gujarat Conditions. Int.J.Curr.Microbiol.App.Sci. 7(05): 34-42. doi: https://doi.org/10.20546/ijcmas.2018.705.005 